\title{
Safety Measures and Safety Warning Signages of Road Construction Projects: An Assessment
}

\author{
Jeed Ignacio ${ }^{1}$, Eraldjean Santos ${ }^{2}$, Patrick Socorro ${ }^{3}$, Dr. Noel Florencondia ${ }^{4}$, Dr. \\ Lorinda Pascual ${ }^{5}$, Dr. Gener Subia ${ }^{6}$
}

${ }^{1,2,3}$ Students, Master of Engineering Management (Graduate School-NEUST)

${ }^{4,5}$ Faculty, Master of Engineering Management (Graduate School-NEUST)

${ }^{6}$ Faculty, Graduate School, Wesley an University Philippines (WUP)

\begin{abstract}
This research described the safety measures and safety warning signages of road construction projects in the first and second legislative districts in the province of Nueva Ecija.Forty (40)road motorists and ten engineers who were familiar with roads and road constructions safety procedures were asked to assess the safety qualities of the projects. The data gathered by the researchers were tallied and tabulated using frequency, percentage and weighted mean.

It was found that the Personal Protective Equipment (PPE) used during construction was properly implemented. There were sufficient warning signs and barriers on the road projects. Oftentimes, there was good traffic management to control the flow of traffic passing through the construction site.

However, the traffic signs were sometimes visible and warning signs were often unreadable for drivers especially at night.
\end{abstract}

Keywords-Assessment, barriers, road construction, road safety, safety measures, warning signs.

\section{INTRODUCTION}

An efficient road is crucial for the country's economic growth and poverty reduction. It is critical as social arteries for the delivery of government services and distribution of technology to the people. Therefore, it is just necessary to construct a road for a more progressive community. Yet, in the process of the construction of roads, there are necessary things that should be given attention not just the construction alone but also the safety of the motorists passing on the site.

Road accidents were mainly caused by driver's errors, mechanical defect, over speeding, drinking spree before driving and lastly, damaged roads or roads under construction without proper warnings [1].

In Nueva Ecija, Philippines, because ofthe continuing progress of the province, there were many roads that were constructed. Therefore, there are higher riskson the construction of roads that motorists may bump into, especially at night.

A lot of motorists encounter accidents when vehicles have to pass through the construction roads and more likely, fatal accidents occurred because of lack of warnings and signage on the area of the site. Some motorists didn't have the chance to slow down because there were no warnings that were placed meters before the exact road construction.

Safety should not be set aside because it is considered as one of the most important things to prioritize in a construction project. The safety of the people working on the site, the motorists and the people involved in the road construction projects should be protected at all times. Lack of safety warning signs visible on the site means that there are more accidents that will most likely occur. There are inconveniences on the people passing on a road project if there are insufficient project safety warning and signage.

This research assessed the safety warning signs and safety measures of the road construction projects in Nueva Ecija that will probably reduce the accidents of the motorists, especially at night. The research aimed to provide information about the safety management of road projects.It aimed to educate the readers that the contractors shall not be held liable for the accident occurred in a construction site if they complied with the contract documents and performed the proper traffic safety plan of the project [2]. Common road construction mistakes that lead to accidents are improper signage, requiring motorists to negotiate too sharp a turn, leaving a dangerous condition in the pavement and 
poor road conditions once construction has been completed [3]. All these mistakes are part of both during and after the construction of the road.

The finding of this study will serve as relevant data to the researchers to be able to make accurate decisions given available information [4] to come up with sufficient safety and management plan that will reduce vehicular accidents in road construction sites. Thus, this study finds meaning and relevance.

\section{METHODOLOGY}

This research uses descriptive survey research design. Survey research design is a very useful tool to analyze opinions and trends [5]. The instrument used in this research was a close-ended questionnaire [6]. It is a cross-sectional survey that collected the information from the respondents in a single period of time [6]. The closed-ended question has scale selection of strongly agree, agree, neutral, disagree and strongly disagree. The validity used in the research was both face and content validity. The face validity is the measurement that involves the personal judgment of the respondents while the content validity uses an approach based on statistics [7].

The respondents of the study were chosen purposively based on the following criteria [8]: they were motorists who were characterized based on the time and how long they drive and encounter the road construction site; how frequent they travel per week and how long they have been driving since they started; another were engineers/ architects who were project inspectors of a road construction project. When combined, face and content validity together with the strong approach of the questionnaire will lead to a strong type of validity. The statistical tools used in this research were the frequency, percentage and mean.

\section{RESULTS AND DISCUSSION}

\section{Assessment of the Safety of Traffic and Warning Signs}

Table 1. Assessment of the Safety of Traffic and Warning Signs

\begin{tabular}{|c|c|c|c|}
\hline & Question & $\begin{array}{l}\text { Weighted } \\
\text { Mean }\end{array}$ & $\begin{array}{c}\text { Verbal } \\
\text { Description }\end{array}$ \\
\hline 1 & Traffic signs are visible from afar. & 3.38 & Sometimes \\
\hline 2 & Warning signs are understandable from afar. & 3.48 & Often \\
\hline 3 & Are there sufficient warning signs displayed to ensure no accident would occur? & 3.45 & Often \\
\hline 4 & Are there sufficient safety barriers to separate the area from passing motorists? & 3.58 & Often \\
\hline 5 & $\begin{array}{l}\text { From your perception, is it convenient if there is traffic management } \\
\text { implemented to control the flow of traffic passing through? }\end{array}$ & 4.15 & Often \\
\hline 6 & $\begin{array}{l}\text { During the night, do you visibly see traffic/warning signs informing that you are } \\
\text { approaching in on-going road construction? }\end{array}$ & 3.15 & Not sure \\
\hline 7 & Are the traffic signs noticeably reflect from your point of view? & 3.24 & Not sure \\
\hline 8 & Are the warning signs noticeably reflect from your point of view? & 3.41 & Fairly yes \\
\hline \multirow[t]{2}{*}{9} & Are the barriers visibly reflect to see that some areas are not passable? & 3.50 & Fairly yes \\
\hline & Overall Weighted Mean & 3.48 & $\begin{array}{l}\text { Often \& Fairly } \\
\text { yes }\end{array}$ \\
\hline
\end{tabular}

Table 1 shows that the respondents find the traffic signs as sometimes visible from a point of distance or from afar (W.M. = 3.38). Pointed out that often, warning signs are understandable from afar (W.M. = 3.48), there are often sufficient warning signs displayed to ensure no accident would occur (W.M. = 3.45), safety barriers are also often sufficient to separate the area from the passing motorists (W.M. = 3.58) and in the perception of the motorists, it is often convenient if there is traffic management implemented to control the flow of traffic passing through (W.M. = 4.15). In a similar manner, the road safety warnings and barriers are often sufficient for the road construction and it is more convenient to implement traffic management to control the flow of traffic passing through the construction site.

For the respondents that are well versed in driving at night, they are not sure about the visibility of traffic/warning signs informing that they are approaching in an on-going road 
construction (W.M.= 3.15) and that they are also not sure about the traffic signs being noticeably reflecting from their point of view (W.M.= 3.24). However, the warning signs are often (fairly yes) noticeable to reflect from their point of view (W.M. = 3.41) and also the barriers are fairly noticeable to reflect some of the areas that are not passable (W.M. = 3.50).

\section{Assessment on the Safety of Road Construction}

Table 2. Assessment on Safety of Road Construction

\begin{tabular}{|r|l|c|c|}
\hline & \multicolumn{1}{|c|}{ Question } & Weighted Mean & $\begin{array}{c}\text { Verbal } \\
\text { Description }\end{array}$ \\
\hline 1 & Occupational Safety and Health Program is strictly implemented. & 3.80 & Often \\
\hline 2 & $\begin{array}{l}\text { Personal Protective Equipment (PPE) was used during } \\
\text { construction. }\end{array}$ & 4.00 & Often \\
\hline 3 & Sufficient warning signs were installed. & 3.50 & Often \\
\hline 4 & Sufficient barriers were installed. & 3.60 & Often \\
\hline 5 & $\begin{array}{l}\text { The contractor practices safety for his/her workers, equipment, } \\
\text { and the passers-by. }\end{array}$ & 3.60 & Often \\
\hline 6 & $\begin{array}{l}\text { The contractoris fully responsible, even if he/she follows proper } \\
\text { safety procedures when an accident occurs. }\end{array}$ & 3.90 & Often \\
\hline & \multicolumn{1}{|c|}{ Overall Weighted Mean } & 3.73 & Often \\
\hline
\end{tabular}

Table 2 shows that in the road construction sites, Occupational Safety and Health Program is strictly implemented (W.M. = 3.80), Personal Protective Equipment (PPE) was used during construction (W.M. = 4.00), sufficient warning signs (W.M. =3.50) and Sufficient barriers were installed (W.M. = 3.60). The contractors frequently practice safety for their workers, equipment, and for the passers-by (W.M. = 3.60) and the contractor is fully responsible, even if he/she follows proper safety procedures, when an accident occurs (W.M. = 3.90).

\section{CONCLUSIONS AND RECOMMENDATIONS}

The study found that the Personal Protective Equipment (PPE) used during construction, the sufficiency of warning signs and barriers and the practice of safety for the workers, equipment and the passers-by were usually sufficient and implemented according to the assessment conducted on the survey for the inspectors of the road project. The result of the assessment from the motorist respondents has also resulted in an often-understandable warning sign, sufficient barriers, and traffic management to control the flow of traffic passing through the construction site. However, the traffic signs are sometimes visible from afar only. In the night, the traffic signs and warning signs are often reflecting from the point of view of the driver but only occasionally readable from a distinct distance.
Finally, the recommendations on this research were based also on the comments from the third part of the survey form. It turns out that traffic is sometimes caused by the traffic aide working on the site. It will be more convenient if the traffic aide is well trained to handle the flow of the vehicles. Accessible detour should also be improved and should equip with proper warning and traffic signage. In addition, it is also advised to have signs from $200 \mathrm{~m}, 100 \mathrm{~m}$, and $50 \mathrm{~m}$ before the construction site for the motorists to at least reduce their speed and prevent accidents. Furthermore, improved and upgraded safety equipment is also a good solution to reduce traffic and avoid accidents on the road site construction. Lastly, research to study and explore the performance [9] of drivers in understanding road signs and markings should be undertaken in the future.

\section{REFERENCES}

[1] Tamayo, Adrian Mernilo, Occurrence of Traffic Accidents in the Philippines: An Application of Poisson Regression Analy sis. July 2009 [Online] Available:

https://www.researchgate.net/publication/228310713_Occurr ence_of_Traffic_Accidents_in_the_Philippines_An_Applica tion_of_Poisson_Regression_Analy sis

[2] Pendas Law Firm. When Lack of Road Construction Signs Leads to Injury and Automobile Destruction. August 2016[Online] Available: https://www.pendaslaw.com/whenlack-of-road-construction-signs-leads-to-injury-andautomobile-destruction/ 
[3] Suszek, Andrew, Accident Claims Based on Negligent Road Construction. [Online] Available: https://www.alllaw.com/articles/nolo/auto-accident/claimsbased-negligent-road-construction.html

[4] Subia, Gener S. (2018). Think Like My Teacher (TLMT): A New Method in Assessing Millennial Learners. International Journal of Arts, Humanities and Social Sciences.Volume 3. Issue 1. www.ijahss.com.

[5] Shuttleworth, Martyn, Survey Research Design. July 5, 2008 [Online] Available: https://explorable.com/survey-research-design

[6] Sincero, Sarah Mae, Types of Survey. Retrieved Mar 11, 2019 [Online] Available: Explorable.com: https://explorable.com/ty pes-of-survey

[7] Shuttleworth, Martyn, Content Validity. Retrieved Mar 16, 2019 [Online] Available: Explorable.com: https://explorable.com/content-validity

[8] Subia, G.(2018). Comprehensible Technique in Solving Consecutive Number Problems in Algebra. Journal of Applied Mathematics and Physics, 6, 447-457. doi: 10.4236/jamp.2018.63041.

[9] Subia, G., Amaranto, J., Amaranto, J., Bustamante, J. and Damaso, I. (2019) Chess and Mathematics Performance of College Players: An Exploratory Analysis. Open Access Library Journal, 6, 1-7. doi: 10.4236/oalib.1105195 